\title{
Impact of Agricultural Education on Students' Career Choice: A Survey
}

\author{
https://doi.org/10.3991/ijet.v15i03.11260
}

\author{
Adebayo Omotosho ${ }^{(凶)}$, Emmanuel Asani, Peace Ayegba, Joyce Ayoola \\ Landmark University, Omu-Aran, Nigeria \\ bayotosho@gmail.com
}

\begin{abstract}
Agriculture has become the bedrock of some growing economy in the world but the discovery of crude oil and other resources in a developing country like Nigeria has led to the extreme decline in the practice. Many youths now have either low or no interested in agriculture and the majority of the people that are actively practicing are the older generation.

This study revisits the impact of education on students interest in agriculture as a professional career. The study was carried out in an agriculture-based university with a state of the art equipment. Our findings show that $64 \%$ of agriculture students who participated in this survey are willing to pursue agriculturerelated careers. Likewise, there is a significant relationship between the student's gender and farm ownership, with $84 \%$ of male students likelier to own farms. Also, our results have shown that students in higher levels have more interests in agriculture compared to students at lower levels and this invariably increases the possibilities of their pursuing agriculture-related careers or businesses.
\end{abstract}

Keywords - Agricultural education, student learning, academic performance, farming

\section{Introduction}

Nigeria is located in West Africa with a land mass of 923,768 sq.km measuring about $1,200 \mathrm{~km}$ from east to west and 1,050 km from north to south [1]. Nigeria is generously endowed with abundant natural resources and has the largest economy in sub-Saharan Africa [2]. Its economic growth relies heavily on oil as its main source of foreign exchange earnings and agriculture, as the country is endowed with a variety of vegetation and large farmlands with suitable agro-climatological conditions for crop cultivation and livestock rearing $[3,4,5]$. Many low middle-income countries such as Nigeria, rely on the agricultural sector to provide employment opportunities, food supply and foreign exchange with the exportation of such goods, contributing positively to their economic growth [6]. Several studies have tried to determine the effect of the agricultural sector on Nigeria's economic growth. Most studies found that agriculture has contributed positively to the economic growth of Nigeria [7], while others have found negative effects [8]. In the past, $63 \%$ of Nigeria's GDP was accounted for by the agricultural sector; however, there was a massive decline in agricultural practices due to the discovery of 
oil in the early 1970 s $[9,10]$. The agricultural sector now delivers only a $30.9 \%$ share in the country's GDP [4].

Although the government has introduced numerous agricultural programmes and initiatives to improve agricultural development such as the Agriculture Development Programme, Green Revolution, Operation Feed the Nation, Poverty Alleviation Programme, and the National Special Programme for Food Security, Nigeria still suffers the problem of poverty and food insecurity even with the new focus on agricultural practices because the majority of the farmers are aged between $55-70$ years [11,12]. With the creation of sustainable agricultural policies and programmes as well as the introduction of agricultural science into the school's curriculum, there is now a growing interest and increased agricultural practices amongst the youths, that is, individuals aged between 15 and 35 years; Nigeria's agriculture still has immense potentials in contributing to the nation's economic development and growth $[13,14]$. Many youths are uninterested in farming and would rather enter the labor force as they perceive farming a "poor man's occupation"; this, in turn, has devastating effects on the agricultural sector as youths make up $51.9 \%$ of the world population and $60 \%$ of the Nigerian population $[15,16]$.

Some studies revealed that limited knowledge on agriculture or farming due to increased population, limited access to agricultural information, lack of access to land, youths see agriculture as a course for less privileged and unintelligent, inadequate access to financial services, limited access to market and lack of youths involvement in policy dialogues, are some reasons for the decline in youths participation in agriculture $[17,18,19]$. Even though the youths play a vital role in the country's future development, unfortunately, youth unemployment accounts for $70 \%$ of the unemployment rate in $\mathrm{Ni}$ geria [20]. Youths involvement in agricultural activities will, therefore, reduce the unemployment rate significantly and consistently eradicate food insecurities in Nigeria. There is a need to simulate youths' interest and participation in agricultural activities and make them driving forces in agricultural development. [17] examined the effects of agricultural education and training in motivating students to pursue agriculture-related courses or agri-business. The study showed that although education and training have been effective, there lies the need to incorporate agriculture into the school curriculum especially at early stages [21]. [13] showed that some of the students who desired to be self-employed and have received adequate agricultural education and training are usually willing to pursue agriculture as a career. Education and training were also shown by [22] to be an effective tool in broadening knowledge and enhancing research interests. Embedding agricultural education and research into higher education, and linking this with practical farming activities, has proven beneficial in many countries [23]. Studies have recommended agricultural education at all levels of education and establishment of agricultural research institutes as a means to equip youths with agricultural skills and competencies [24,25]. Students choice of study at higher education is also often influenced by their family background, gender, family economic status, and ethnicity which also determines their willingness to pursue agriculture-related careers [26,27]. Practical agriculture through student industrial work experience scheme and practical farming activities as well the impact of trained agricultural experts has made learning agriculture more interesting and influenced students' attitude to learn 
agriculture especially in the university $[28,29]$. However, studying an agricultural course at a higher education may not always be a prerequisite to becoming an agricultural entrepreneur "agripreneur" or owning an agribusiness.

Many of the surveys on the impact of higher education on selecting agriculture as a career path have been inconsistent, for instance in [14,30,31], this is because they either considered only a small sample of final year students or many non-major agricultural students in federal universities. Our approach is different because we considered students studying agriculture-related courses in an agriculture-based private university in order to get a more refined and usable result. There is a need to investigate the impact of agriculture in higher education and student's perception towards agriculture-related careers, to be able to make future recommendations that will encourage youths to take up agriculture as professions and for sustainable agricultural practices.

The creation of agricultural policies, governments involvement in agriculture, increased use of ICT in agriculture and learning, functional or practical agriculture education (formal and informal), gamification, scholarships to improve tertiary agricultural education and availability of start-up funding opportunities are some recommendations made to enhance students interest in Agriculture [3,28,32,22,24].

\section{$2 \quad$ Methodology}

The study was carried out with a questionnaire which was completed by 85 students studying agriculture-related courses at Landmark University. Landmark University is an agrarian institution and has four colleges namely, the college of engineering, college of business and social science, college of pure and applied science and the college of agricultural science. Although all students in the university compulsory undergo "farm practice" throughout their stay in the university, this study focused on the students in the college of agricultural science and engineering as it is assumed that their affinity and expression towards agriculture as a profession would be more realistic. The questionnaire captured the student's educational background, what influenced their choice of agriculture as a course, their preferred agricultural branch, preferred mode of study, their previous and current interests in studying agriculture, their family background and interests in agriculture, their future plans in pursuing agriculture a career as well as the future prospects of agriculture in Nigeria.

The survey was carried out for a period of 7 days and participants were randomly drawn from students in the second year through the fifth year as they were in a better position to answer many of the related questions than first-year students.

Statistical Package for the Social Sciences (SPSS) software package was used for analyzing the data collected. The data obtained were subjected to descriptive statistics using frequency counts, chi-square analysis and symmetric measures for hypothesis testing. 


\section{Results}

There were 29 students in 200 level, 42 in 300 level, 11 in 400 level and just 3 students in 500 level with a total of 46 female students and 39 male students. The majority (68) of the students were students studying agricultural sciences and others (17) in agricultural engineering. Table 1 shows the distribution of preferred specializations by the students.

61 students have a family member who is an agriculture enthusiast, 54 students reported having a family member who owns a farm but only $11.8 \%$ of the students were influenced by their parents in choosing agriculture as their course of study; Other students chose to study agriculture on their own. Furthermore, 42 students' indicated livestock production is their preferred branch of agriculture; This might be because livestock production is one of the most practical branches of agriculture and Landmark university has a large farm for livestock production and rearing were students can raise and maintain livestock. Also, $86 \%$ of the students preferred fieldwork as a mode of learning rather than classroom learning. All the respondents in this survey agreed that agriculture has great future prospects and that the government should invest more in agriculture and $97 \%$ of students agreed that more agrarian institutions should be developed.

Table 1. Preferred branch of agriculture

\begin{tabular}{|l|c|}
\hline \multicolumn{2}{|c|}{ Preferred branch of agriculture } \\
\hline Livestock Production & 42 \\
\hline Crop Production & 15 \\
\hline Agricultural Economics & 10 \\
\hline Agricultural Engineering & 17 \\
\hline None & 1 \\
\hline
\end{tabular}

\subsection{The current level of interest in agriculture and the likelihood of pursuing agriculture as a career}

A cross-correlation of the student's current level of interest in agriculture and the likelihood of pursuing agriculture as a career is shown in table 2. Of the 85 respondents, 37 students who were "very interested" in agriculture showed they were "very likely" to pursue agriculture as a career. Also, there is a high correlation between the current level of interest in agriculture and the likelihood of pursuing agriculture as a career in future. Table 3 shows the Pearson chi-square $(\mathrm{P}<0.05)$ indicating the likelihood of pursuing agriculture as a career is significantly dependent on the students current level of interest in agriculture. The symmetric measures is a Pearson's R-value greater than 0.5 showing a "strong positive" correlation. We can, therefore, say hypothetically that as the student's interest in agriculture increases, there would be a significant increase in the likelihood of he/she pursuing agriculture as a career. Furthermore, most students are very interested in agriculture and are willing to pursue agriculture as a career. 
Table 2. Student's current level of interest vs likelihood of pursuing an agricultural-related career

\begin{tabular}{|c|c|c|c|c|c|c|}
\hline \multicolumn{7}{|c|}{ Cross-table } \\
\hline & & \multicolumn{4}{|c|}{ Likelihood of pursuing Agric as a career } & \multirow[t]{2}{*}{ Total } \\
\hline & & Unlikely & Neutral & likely & Very likely & \\
\hline \multirow{4}{*}{$\begin{array}{l}\text { The current level of interest in } \\
\text { agriculture }\end{array}$} & Not interested at all & 1 & 1 & 0 & 0 & 2 \\
\hline & Neutral & 1 & 5 & 1 & 3 & 10 \\
\hline & Interested & 1 & 1 & 13 & 15 & 30 \\
\hline & Very interested & 0 & 0 & 6 & 37 & 43 \\
\hline \multicolumn{2}{|l|}{ Total } & 3 & 7 & 20 & 55 & 85 \\
\hline
\end{tabular}

Table 3. Chi-square tests and symmetric measures for student's current level of interest vs likelihood of pursuing an agricultural-related career

\begin{tabular}{|c|c|c|c|c|c|}
\hline \multicolumn{6}{|c|}{ Chi-square test } \\
\hline & Value & & $d f$ & \multicolumn{2}{|c|}{ Asymp. Sig. (2-sided) } \\
\hline Pearson Chi-Square & $59.887^{\mathrm{a}}$ & & 9 & \multicolumn{2}{|c|}{.000} \\
\hline Likelihood Ratio & 43.746 & & 9 & \multicolumn{2}{|c|}{.000} \\
\hline Linear-by-Linear Association & 32.948 & & 1 & \multicolumn{2}{|c|}{.000} \\
\hline $\mathrm{N}$ of Valid Cases & 85 & & & & \\
\hline \multicolumn{6}{|c|}{ Symmetric measures } \\
\hline & & Value & \begin{tabular}{|c|} 
Asymp. \\
Std. Error $^{a}$ \\
\end{tabular} & Approx. $T^{b}$ & Approx. Sig. \\
\hline Interval by Interval & Pearson's R & .626 & .085 & 7.319 & $.000^{\mathrm{c}}$ \\
\hline Ordinal by Ordinal & Spearman Correlation & .542 & .091 & 5.873 & $.000^{\mathrm{c}}$ \\
\hline $\mathrm{N}$ of Valid Cases & & 85 & & & \\
\hline
\end{tabular}

\subsection{Farm owners and pre-university interest in agriculture}

We try to find a correlation between the students who had a pre-university interest in agriculture and those who own farms currently. Table 4 shows that out of the 85 respondents, 13 students currently own a farm and only 10 of the 13 students had a prior interest in agriculture whereas 1 student who did not have any prior interest in agriculture currently owns a farm. Also, we noticed that owning farmland was independent of having a prior interest in agriculture. $36 \%$ of students who do not own farmlands now, had a high interest in agriculture prior to pursuing a degree in it. The analysis in Table 5 showed a Pearson's R-value less than -0.5 (indicating that the correlation is a "strong negative") which affirms there is no relationship between the students that own farms and having a prior interest in agriculture. This also means that although a student doesn't own a farm at the university level, he/she might still become an " agripreneurs", or own an agribusiness. 
Table 4. Farm owners vs pre-university interest in agriculture symmetric measures for student's current level of interest vs likelihood of pursuing an agricultural-related career

\begin{tabular}{|c|c|c|c|c|c|c|}
\hline \multicolumn{7}{|c|}{ Cross-table } \\
\hline & & \multicolumn{4}{|c|}{ Pre-university interest in agriculture } & \multirow[b]{2}{*}{ Total } \\
\hline & & Not interested at all & Neutral & Interested & Very interested & \\
\hline \multirow{2}{*}{ Farm owners } & Yes & 1 & 1 & 1 & 10 & 13 \\
\hline & No & 5 & 13 & 28 & 26 & 72 \\
\hline Total & & 6 & 14 & 29 & 36 & 85 \\
\hline
\end{tabular}

Table 5. Chi-square tests for farm owners and their pre-university interest in agriculture

\begin{tabular}{|c|c|c|c|c|c|}
\hline \multicolumn{6}{|c|}{ Chi-square tests } \\
\hline & Value & \multicolumn{2}{|c|}{$d f$} & \multicolumn{2}{|c|}{ Asymp. Sig. (2-sided) } \\
\hline Pearson Chi-Square & $8.199^{\mathrm{a}}$ & \multicolumn{2}{|c|}{3} & \multicolumn{2}{|l|}{.042} \\
\hline Likelihood Ratio & 8.870 & \multicolumn{2}{|c|}{3} & \multicolumn{2}{|l|}{.031} \\
\hline $\begin{array}{l}\text { Linear-by-Linear Associa- } \\
\text { tion }\end{array}$ & 3.135 & \multicolumn{2}{|c|}{1} & \multicolumn{2}{|l|}{.077} \\
\hline No of Valid Cases & 85 & & & & \\
\hline \multicolumn{6}{|c|}{ Symmetric measures } \\
\hline & & Value & $\begin{array}{l}\text { Asymp. Std. } \\
\text { Error }^{a}\end{array}$ & Approx. $T^{b}$ & $\begin{array}{l}\text { Approx. } \\
\text { Sig. }\end{array}$ \\
\hline Interval by Interval & Pearson's R & -.193 & .112 & -1.794 & $.076^{\mathrm{c}}$ \\
\hline Ordinal by Ordinal & Spearman Correlation & -.239 & .108 & -2.239 & $.028^{\mathrm{c}}$ \\
\hline No of Valid Cases & & 85 & & & \\
\hline
\end{tabular}

\subsection{Gender and farm owners}

A total of 13 students, 11 male, and 2 female students, own farms. Although $60 \%$ of the respondents are female students, only $3 \%$ of them own farms, whereas $32 \%$ of the male students currently own farms as shown in Table 6 . The chi-square tests in Table 7, was used to outline a correlation between the student's gender and farm ownership, and we see that there is a significant relationship between a students gender and his/her likelihood of owning a farm, implying male students are more likely to own farms compared to female students.

Table 6. Cross table correlation between male and female farm owners

\begin{tabular}{|c|c|c|c|c|}
\hline \multicolumn{5}{|c|}{ Cross-table } \\
\hline & & \multicolumn{2}{|c|}{ Farm owners } & \multirow[t]{2}{*}{ Total } \\
\hline & & Yes & No & \\
\hline \multirow{2}{*}{ Sex } & Male & 11 & 23 & 34 \\
\hline & Female & 2 & 49 & 51 \\
\hline Total & & 13 & 72 & 85 \\
\hline
\end{tabular}


Table 7. Chi- Chi-square test of male and female farm owners

\begin{tabular}{|c|c|c|c|c|c|c|}
\hline \multicolumn{7}{|c|}{ Chi-square tests } \\
\hline & & Value & $d$ & $\begin{array}{c}\text { Asymp. Sig. (2- } \\
\text { sided) }\end{array}$ & $\begin{array}{l}\text { Exact Sig. (2- } \\
\text { sided) }\end{array}$ & $\begin{array}{l}\text { Exact Sig. (1- } \\
\text { sided) }\end{array}$ \\
\hline Pearson Chi-Square & & $12.729 \mathrm{a}$ & 1 & .000 & & \\
\hline Continuity Correctio & & 10.629 & 1 & .001 & & \\
\hline Likelihood Ratio & & 13.041 & 1 & .000 & & \\
\hline Fisher's Exact Test & & & & & .001 & .001 \\
\hline Linear-by-Linear As & sociation & 12.579 & 1 & .000 & & \\
\hline $\mathrm{N}$ of Valid Cases & & 85 & & & & \\
\hline \multicolumn{7}{|c|}{ Symmetric measures } \\
\hline & & & Value & Asymp. Std. Error ${ }^{a}$ & Approx. $T^{b}$ & Approx. Sig. \\
\hline Interval by Interval & \multicolumn{2}{|l|}{ Pearson's R } & .387 & .093 & 3.823 & $.000^{\mathrm{c}}$ \\
\hline Ordinal by Ordinal & \multicolumn{2}{|c|}{ Spearman Correlation } & .387 & .093 & 3.823 & $.000^{\mathrm{c}}$ \\
\hline \multicolumn{3}{|l|}{$\mathrm{N}$ of Valid Cases } & 85 & & & \\
\hline
\end{tabular}

\subsection{Students' level and current level of interest in agriculture}

From Table 8 , we see that out of the 43 students who are very interested in agriculture, the highest number(11 students) are in their third year. Only 2 and 7 students in 400 and 500 level respectively are very interested in agriculture although this might be due to the low number of students in these levels, for instance, there are only a total of 3 students in 500 level.

The Pearson chi-square test as shown in Table 9, has a p-value less than 0.05 $(\mathrm{P}<0.05)$, which shows that the students' level of interest in agriculture is dependent on their current level in the university. Also, the Pearson R value $>0.05$ shows a "strong positive" correlation. We can, therefore, deduce that as the students move to a higher level, his/her interest in agriculture is increased also.

Table 8. Students' level vs current level of interest in an agriculture chi-square test of male and female farm owners

\begin{tabular}{|c|c|c|c|c|c|c|}
\hline \multirow{2}{*}{\multicolumn{2}{|c|}{ Interest in agriculture }} & \multicolumn{4}{|c|}{ Level } & \multirow[t]{2}{*}{ Total } \\
\hline & & 200 & 300 & 400 & 500 & \\
\hline \multirow{4}{*}{ The current level of interest in agriculture } & Not interested at all & 0 & 1 & 0 & 1 & 2 \\
\hline & Neutral & 3 & 7 & 0 & 0 & 10 \\
\hline & Interested & 12 & 14 & 4 & 0 & 30 \\
\hline & Very interested & 14 & 20 & 7 & 2 & 43 \\
\hline Total & 29 & 42 & 11 & 3 & 85 & 85 \\
\hline
\end{tabular}


Table 9. Table Chi-square tests for students' level vs current level of interest in agriculture

\begin{tabular}{|c|c|c|c|c|c|}
\hline \multicolumn{2}{|c|}{ Chi-Square Tests } & Value & df & \multicolumn{2}{|c|}{ Asymp. Sig. (2-sided) } \\
\hline \multicolumn{2}{|l|}{ Pearson Chi-Square } & $17.773^{\mathrm{a}}$ & 9 & \multicolumn{2}{|c|}{.038} \\
\hline \multicolumn{2}{|l|}{ Likelihood Ratio } & 12.473 & 9 & \multicolumn{2}{|c|}{.188} \\
\hline \multicolumn{2}{|c|}{ Linear-by-Linear Association } & .000 & 1 & \multicolumn{2}{|c|}{.986} \\
\hline \multicolumn{2}{|l|}{$\mathrm{N}$ of Valid Cases } & 85 & & & \\
\hline \multicolumn{2}{|c|}{ Symmetric measures } & Value & $\begin{array}{c}\text { Asymp. Std. } \\
\text { Errora }\end{array}$ & Approx. Tb & Approx. Sig. \\
\hline Interval by Interval & Pearson's R & .002 & .131 & .017 & $.987^{\mathrm{c}}$ \\
\hline Ordinal by Ordinal & Spearman Correlation & .052 & .107 & .475 & $.636^{\mathrm{c}}$ \\
\hline $\mathrm{N}$ of Valid Cases & & 85 & & & \\
\hline
\end{tabular}

\section{Concluding Remark}

The agricultural sector can be a major contributor to the economic development of a nation and there is a need to attract the young generation through modern education to see the need for agricultural practices. In this work, we carried out a survey to evaluate the impact of agricultural education on students of agriculture-related courses at Landmark University.

Our findings showed that $64 \%$ of agriculture students who participated in this survey are willing to pursue agriculture-related careers; which is better and justifies a progressive increase from what was obtained (57\%) in the most recent study by [31] who studied the perception of final year agriculture students in taking up farming as a means of livelihood or venturing into agriculture-related enterprises after graduation. $46.5 \%$ of students who indicated high interests in studying agriculture as a course, were in their third year (300 level). Interestingly, only $15.2 \%$ of students currently own farmlands and a majority of them (11.8\%) had a prior interest in studying agriculture as a course. This implies that if the government can make lands available for farming, it can have a direct influence on the practical application after studies.

In summary, this survey has analyzed the relationship between the student's preuniversity interests, current interests in agriculture and the future possibilities of pursuing agriculture-related careers or businesses at their different levels particularly in a private university whereas previous studies have focused on students in federal universities. Also, many of the respondents prefer hands-on farming activities to classroom learning; It is, therefore, important to integrate practical farming activities to agricultural education in order to enhance students' interest in taking agriculture as a profession. The use of technologies and incentives that boost agricultural education and farming activities should be made available to all students, to motivate them in becoming "agripreneurs" or own agribusinesses in order to eliminate food insecurity in Nigeria. 


\section{$5 \quad$ References}

[1] Embassy of the Federal Republic of Nigeria, 2013). Geography, Climate, and Vegetation. Retrieved from: http://www.nigeriabeirut.org/about-nigeria/geography-climate-and-vegetation/ (accessed 21/6/2019).

Forbes (2019). Nigeria, At a glance. Retrieved from: https://www.forbes.com/p laces/nigeria/. (accessed 21/6/2019)

[3] Sertoglu, K., Ugural, S., \& Bekun, F. V. (2017). The contribution of the agricultural sector on economic growth of Nigeria. International Journal of Economics and Financial Issues, $7(1), 547-552$.

[4] CIA worldfactbook (2018). Nigeria Economy Profile 2018. Retrieved from: https://www.indexmundi.com/nigeria/economy profile.html. (accessed 20/6/2019).

[5] Alene, A.D., Manyong, V.M., Omanya, G., Mignouna, H.D., Bokanga, M., Odhiambo, G. (2008), Smallholder market participation under transactions costs: Maize supply and fertilizer demand in Kenya. Food Policy, 33(4), 318-328. https://doi.org/10.1016/j.foodpol. 2007.12.001

[6] Izuchukwu, O. (2011), Analysis of the contribution of agricultural sector on the Nigerian economic development. World Review of Business Research, 1(1), 191-200.

[7] Ahungwa, G., Haruna, U., Abdsalam, Y.R. (2012), Trend analysis of the contribution of agriculture to gross domestic product (1960-2012). Journal of Agricultureal and Veterinary Science, 7(1), 50-55.

[8] Oluwatoyese, O.P., Applanaidu, S.D. (2013), Effect of agricultural, manufacturing and service sector performance in Nigeria, 1980-2011. Journal of Economics and Sustainable Development, 4, 35-41.

[9] Aigbokha, B. (2001), Resuscitating Agricultural Production (Cocoa, Cotton, Groundnut, Palm Oil, Rubber etc.) for Export CBN Proceedings of the 10th Annual Conference of the Zonal Research Unit, Ibadan, April, 13-16.

[10] Central Bank of Nigeria (2003). Statistical Bulletin, Central Bank of Nigeria.

[11] Njeru K.L, Gichimu B.M,Lopokoiyit C.M, and Mwangi G.J (2015). Influence of Kenyan Youth's Perception towards agriculture and necessary intervention; A Review. Asian Journal of Agricultural Extension, economics and sociology. 5(1): 40-45. https://doi.org/10. 9734/ajaees/2015/15178

[12] Dauda, R. S. (2017). Poverty and economic growth in Nigeria: Issues and policies. Journal of Poverty, 21(1), 61-79. https://doi.org/10.1080/10875549.2016.1141383

[13] Ojebiyi, W. G., Ashimolowo, O. R., Soetan, O. S., Aromiwura, O. A., \& Adeoye, A. S. (2015). Willingness to Venture into Agriculture-related Enterprises after Graduation among Final Year Agriculture Students of Federal University of Agriculture, Abeokuta. International Journal of Applied Agriculture and Apiculture Research, 11(1-2), 103-114.

[14] Muhammad-Lawal, A., \& Atte, O. A. (2016). An analysis of agricultural production in Nigeria. African Journal of General Agriculture, 2(1), 1-6.

[15] World population review (2019). Nigeria population 2019. Retrieved from: http://worldpopulationreview.com/countries/nigeria-population/ (accessed 20/6/2019)

[16] Vision2010 report, (2005). Vision 2010 report full text. Retrieved from: https://nigeriaworld.com/focus/documents/vision2010.html (access 20/6/2019)

[17] Haggblade, S., Chapoto, A., Drame-Yayé, A., Hendriks, S. L., Kabwe, S., Minde, I., \& Terblanche, S. (2015). Motivating and preparing African youth for successful careers in agribusiness: insights from agricultural role models. Journal of Agribusiness in Developing and Emerging Economies, 5(2), 170-189. https://doi.org/10.1108/jadee-01-2015-0001 
[18] Agumagu, A. C., Ifeanyi-Obi, C. C., \& Agu, C. (2018). Perception of agriculture students towards farming as a means of sustainable livelihood in Rivers State, Nigeria. Journal of Agricultural Extension, 22(1), 109-116.

[19] Okiror J.J, and Otabong D. (2015). Factors influencing career choice among undergraduate Students in an African university context: The Case of Agriculture Students at Makerere University, Uganda. Journal of Dynamics in Agricultural Research. 2(2):12-20.

[20] National bureau of statistics (2018, December). Labor Force Statistics - Volume I: Unemployment and Underemployment Report. Retrieved from: https://nigerianstat.gov.ng/down-

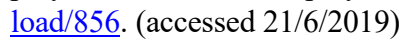

[21] Mugisha, J., \& Nkwasibwe, A. (2014). Tracer study of agricultural graduates in Uganda (No. 1093-2016-87893).

[22] IFAD, F. (2014). Youth and agriculture: Key challenges and concrete solutions. Published by the Food and Agriculture Organization of the United Nations (FAO) in collaboration with the Technical Centre for Agricultural and Rural Cooperation (CTA) and the International Fund for Agricultural Development (IFAD). Rome. https://doi.org/10.18356/7392 c291-en

[23] Blackie, M., Mutema, M., Ward, A., Sheets, F., OER, R., \& SCARDA, R. (2009). A study of Agricultural Graduates in Eastern, Central and Southern Africa: Demand, Quality and Job Performance issues. A report to ASARECA and RUFORUM.

[24] Amadi, N. S., \& Lazarus, S. T. (2017). Current Issues in Agricultural Education in Tertiary Institutions in Nigeria. International Journal of Agriculture and Earth Science, 3(1), 13-18.

[25] Girgin, A. (2011). The Role of Education in Agricultural Productivity: The Case of Village Institutes in Turkey, 1940-1966.

[26] Hammond, C., Linton, D., Smink, J., \& Drew, S. (2007). Dropout risk factors and exemplary programs, a technical report, National Dropout Prevention Centre at Clemson. Retrieved from: https://files.eric.ed.gov/fulltext/ED497057.pdf

[27] Barau, A. A., \& Adesiji, G. B. (2018). Socioeconomic Determinants Influencing the Willingness of Agriculture Undergraduates to Participate in Agripreneurship in Northwest Nigeria. International Journal of Agricultural Management and Development, 8(1), 25-34.

[28] Otekunrin, O. A., Otekunrin, O. A., \& Oni, L. O. (2019). Attitude and Academic Success in Practical Agriculture: Evidence from Public Single-Sex High School Students in Ibadan, Nigeria. Asian Journal of Advanced Research and Reports, 1-18. https://doi.org/10.9734/ ajarr/2019/v4i330111

[29] Saliu, O. J. (2016). Perception of Kogi State University Agricultural Students on Farming as a Career. International Journal of Sustainable Agricultural Research, 3(4), 72-81.

[30] Akintayo, O. I., \& Lawal, B. O. (2015). Willingness of youth to practise agriculture: Implications for farm succession and sustainable farming systems in Nigeria. South-West Farming Systems Research and Extension Programme, Institute of Agricultural Research and Training, Moor Plantation, Ibadan, Oyo State, Nigeria. https://doi.org/10.155 80/gjas.2019.1.020719026

[31] Adesoji, S. A., Famakinwa, M., \& Eghosa, A. E. (2019). Assessment of Agricultural Extension Students' Interest in Providing Private Extension Services in Nigeria. Assessment, 14(1), 57-66. https://doi.org/10.4038/jas.v14i1.8457

[32] Omotosho, A., Tyoden, T., Ayegba, P., \& Ayoola, J. (2019). Gamified Approach to Improving Student's Participation in Farm Practice--A Case Study of Landmark University. International Journal of Interactive Mobile Technologies, 13(5), 94 - 109. https://doi.org/ $\underline{10.3991 / i j i m . v 13 i 05.9404}$ 


\section{Authors}

Adebayo Omotosho received his $\mathrm{PhD}$ in Computer Science at Ladoke Akintola University of Technology in 2016. He is a Seasoned Computer Programmer and has taken part in several programming competitions in $\mathrm{C} / \mathrm{C}++/ \mathrm{CH}$. He is a member of the Nigeria Computer Society (NCS), Computer Professional [Registration Council] of Nigeria (CPN), Computer Science Teachers Association for Computing Machinery (ACM), and International Association of Computer Science and Information Technology. His research interests are health informatics, computer security, machine learning, and biometrics.bayotosho@gmail.com

Emmanuel Oluwatobi Asani is a faculty member of the Department of ComputerScience, Landmark University, Omuaran, Nigeria. His research interest bothers on modelling of mathematical and statistical theories using soft computing tools to solve cyber and information security problems. He has attended and presented papers in both local and international journal with his research efforts appearing in local and international peer reviewed journals. In August 2015, he was honoured at the iSTEAM MINTT conference held at the University of Benin for his contributions to scientific research. asani.emmanuel@lmu.edu.ng

Peace Ayegba is a research assistant in the Department of Computer Science, Landmark University Omu-Aran. She is currently on her MSc degree and her research areas are computer security, human-computer interaction, artificial intelligence and e-health. ayegba.peace@lmu.edu.ng

Joyce Ayoola is a graduate assistant in the Department of Computer Science, Landmark University Omu-Aran. She is currently on her MSc degree and her research areas are computational complexity and software development. ayoola.joyc e@ $@$ lmu.edu.ng

Article submitted 2019-07-12. Resubmitted 2019-08-12. Final acceptance 2019-08-12. Final version published as submitted by the authors. 